UDC 330.2

DOI: $10.15673 /$ fie.v11i4.1547

\author{
Durbalova N. \\ Postgraduate student \\ Department of Management and Logistics \\ E-mail: durbalova.nataly@ukr.net \\ ORCID: 000-0002-0739-1265 \\ Sedikova I. \\ Doctor of Economics, Professor \\ Department of Management and Logistics \\ Odessa National Academy of Food Technologies \\ Kanatna str., 112 Odesa, Ukraine, 65039 \\ E-mail: irina-sedikova@ukr.net \\ ORCID ID: 0000-0003-4376-1267
}

\title{
STRATEGIC MANAGEMENT COMPETITIVE POTENTIAL OF THE ENTERPRISE
}

The purpose of this article is to scientifically substantiate methods and develop tools for managing the competitive potential of enterprises. The main strategies for the development of the baking industry have been outlined, namely: for the enterprises with a high level of utilization of competitive potential the most cost-effective strategy will be adequate; for enterprises with an average level of utilization of competitive potential the integration strategy is recommended; a differentiation strategy is recommended for an enterprise with low competitive potential. It was emphasized that a niche strategy should be one of the key strategies for the development of the industry, providing sustainable competitive advantages. Managing the competitive edge of the businesses being researched should be related to the product component.

Key words: strategy, bakeries, competition, market, potential.

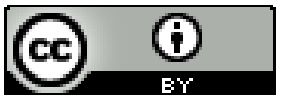

This work is licensed under a Creative Commons Attribution 4.0 International License http://creativecommons.org/licenses/by/4.0/
Statement of the problem and its connection with important scientific and practical tasks. Ensuring long-term competitiveness of enterprises is the most important task in the current conditions of their operation. This is due to structural changes in the economy and the emergence of new players in the market. In such circumstances, the stability of functioning, the sustainability of the development of existing enterprises should be ensured by creating effective competitive advantages. Given the high degree of variability in the environment in which businesses operate, a competitive strategy must be transformative. Solving the problem of forming and managing the competitiveness of an enterprise in the market is one of the functions of strategic management. For the baking industry, it is important to form a system of strategic management of competitiveness.

The current stage of development of the food industry is characterized by increased competition in the food market, which is reaching new global players, which leads to a significant redistribution of market influence. Thus, the supply on the market of bread and bakery products is being formed not only by large industrial producers, but also by small enterprises and retail trade networks.

Strategic management allows businesses to increase their planning horizons, to ensure effective management of competitive advantages. At the same time, the problem of strategic management of enterprise competitiveness remains underdeveloped. Thus, the practical importance and insufficient scientific elaboration of the issues of managing the competitiveness of enterprises in a market environment have determined the relevance and necessity of this research.

The analysis of the latest publications on the problem. Issues related to competitiveness management are dealt with in the works of M. Albert, G. Armstrong, P. Draker, F. Kotler, M. Mescon, M. Porter and other scholars. Issues related to ensuring effective strategic management of enterprise development are dealt with in the works of I. Ageeva, G. Azoev, B. Andrushkiv, Y. Dyachenko, Z. Borysenko, A. Voychak, O. Humeniuk, J. Zhalila, R. Kamishnikov, L. Malyuta, O. Nikishina, R. Fatkhutdinova, O. Tsarenko and others.

However, there are a number of unresolved issues in the formulation of competitiveness policy as an object of strategic management. New approaches to the management of long-term competitiveness, its individual factors in order to determine the main directions of optimal use of resources have determined the purpose of the study.

Forming of the aims of the research. The purpose of this article is to scientifically substantiate methods and develop tools for managing the competitive potential of enterprises. 
Giving an account of the main results and their substantiation. Competitiveness management is the formation of a certain level of a competitive potential. As the competitive potential management entails the formation of long-term sustainable competitive advantages, there is a clear relationship between competitiveness management and strategic management. Strategic management should ensure the effective life of the enterprise. This means maintaining it as a business entity within the existing factors, creating the conditions for growth, development, sustainability. Based on systemic, institutional, strategic approaches, competitive potential can be defined as a complex of financial-investment, production, innovation and human resources that an enterprise uses to create competitive advantages in the long run and to respond adequately to the changing environments.
The analysis of the state of the baking industry showed that the main trend in this industry is the reduction of production volumes. The decline in bread production and consumption is driven by a number of factors. These factors include the decrease in the population of the country, changes in consumer preferences, changes in income levels, and the decline in bread and bakery production occurs against the backdrop of low capacity utilization.

According to the State Committee of Statistics of Ukraine, the production of bread and bakery products in 2018 decreased by $9.8 \%$ compared to 2017 and amounted to 468 thousand tons, the production of wheat and wheatrye flour decreased by $8.1 \%$ and amounted to 819 thousand tonnes [1]. Table 1 shows the dynamics of production of certain types of industrial products for 2011-2018.

Table 1

Output of some types of industrial products for 2011-2018

\begin{tabular}{|l|c|c|c|c|c|c|c|c|c|c|c|}
\hline \multirow{2}{*}{$\begin{array}{l}\text { Product name by the nomencla- } \\
\text { ture of products of industry (the } \\
\text { nomenclature) }\end{array}$} & \multirow{2}{*}{ Unit } & \multicolumn{7}{|c|}{ Volume of output of industrial products } \\
\cline { 3 - 11 } & & 2011 & 2012 & 2013 & 2014 & 2015 & 2016 & 2017 & 2018 \\
\hline & mln.t & 2,4 & 2,4 & 2,4 & 2,2 & 2,1 & 2,0 & 2,0 & 1,7 \\
\hline Wheat or meslin flour & mln.t & 1,8 & 1,7 & 1,6 & 1,4 & 1,2 & 1,2 & 1,1 & 1,0 \\
\hline $\begin{array}{l}\text { Bread and bakery products, short } \\
\text { storage }\end{array}$ & manufacturing \\
\hline $\begin{array}{l}\text { Sweet biscuits (including sand- } \\
\text { wich biscuits; excluding those } \\
\text { completely or partially coated or } \\
\text { covered with chocolate or other } \\
\text { preparations containing cocoa) }\end{array}$ & thsd.t & 229 & 241 & 237 & 184 & 167 & 163 & 177 & 171 \\
\hline $\begin{array}{l}\text { Waffles and wafers (including } \\
\text { salted) (excluding those com- } \\
\text { pletely or partially coated or } \\
\text { covered with chocolate or other } \\
\text { preparations containing cocoa) }\end{array}$ & thsd.t & 65,4 & 72,4 & 74,6 & 54,3 & 47,9 & 49,5 & 51,0 & 51,2 \\
\hline
\end{tabular}

* developed by the author

The bakery segment consists of rye bread and wheat-rye bread - $32 \%$, bakery products - $25 \%$, wheat bread $-42 \%$, rye bread $-1,1 \%$, dietary bread $-0,1 \%$, other bread $-0.4 \%$ [1]. The bakery segment consists of rye bread and wheat-rye bread $-32 \%$, bakery products $-25 \%$, wheat bread $-42 \%$, rye bread $-1,1 \%$, dietary bread $0,1 \%$, other bread $-0.4 \%[1]$.

Market analysts predict a further decline in bread consumption: "... the activity of producers should move to a small, filled niche of dietary bread products (protein, yeast-free bread), products with various useful additives, as the movement for healthy nutrition, which promotes the need for healthy food, is gaining in popularity. . A partial switch to "niche" bread varieties would help producers offset the narrowing of the traditional market "[2].

There are currently three groups of participants in the bread and bakery market:

1. Traditional producers - large and mediumsized enterprises

2. Mini-bakeries;
3. Network retail trading companies (production of bakery products from semi-finished products).

About $60 \%$ of the domestic market is occupied by the six largest companies, namely: PJSC "Kyivkhlib", LLC "Bread Holding" Khlibny Investments ", PJSC" Concern "Khlibprom", LLC "Bakery Complex" Kulinichi ", GK" Formula of Taste ", GK" Khlibodar" ", Holding" Golden Harvest "by Lauffer Group. The share of mini-bakeries is $10 \%$, and the remaining $30 \%$ of national bread and bakery production is provided by more than 100 bakeries. Each group of participants has its own focus on certain segments of the market. The orientation of different producer groups in different segments of the bread and bakery market is shown in table 2 .

As can be seen from table 2, the three groups of market participants have different orientations for market segments. This is due to their competitive advantages and the strengths / weaknesses of the enterprise. In today's conditions, the operation of the baking industry, competitiveness management must be based on the development of a long-term development strategy. 
Orientation of bread and bakery market participants in market segments *

\begin{tabular}{|l|c|c|c|}
\hline \multicolumn{1}{|c|}{ Market segments } & $\begin{array}{c}\text { Traditional man- } \\
\text { ufacturers }\end{array}$ & $\begin{array}{c}\text { Retail network- } \\
\text { ing }\end{array}$ & Mini bakeries \\
\hline 1. By types of products & & & 2 \\
\hline 1.1. Bread & 1 & 1 & 1 \\
\hline 1.2. Long loaves & 1 & 2 & 1 \\
\hline 1.3. Small pieces and pastries & 2 & 1 & 2 \\
\hline 1.4. Bakery products with useful additives & 2 & & 2 \\
\hline 2. By price categories & 1 & 2 & 1 \\
\hline $\begin{array}{l}\text { 2.1. Adjustable prices for bread of "social" demand } \\
\text { (socially significant bread varieties) }\end{array}$ & 2 & 1 & \\
\hline $\begin{array}{l}\text { 2.2. Unregulated prices for non-traditional bakery } \\
\text { products }\end{array}$ & & & 1 \\
\hline 3. By market levels & 1 & 2 & 3 \\
\hline 3.1. Local markets & 2 & 1 & 3 \\
\hline 3.2. Regional markets & 3 & 1 & 2 \\
\hline 3.3. National market & & & \\
\hline
\end{tabular}

Note: 1 is the main niche; 2 - not the main niche; 3 - the manufacturer is not represented in this segment.

* own development

This will offset the weaknesses and existing problems of baking businesses, driven by the predominance of short-term goals.

Enterprise competitiveness management should be based on a proactive approach to strategic management. Bakeries should play an active role in interacting with the external environment and, in addition carry out monitoring of the competitiveness management strategy on-line.

Increasing the competitive potential of an enterprise should be based on the management of strategic assets and competencies of the enterprise. The classic view of strategic assets is resources that outperform competitors in terms of their assets. Strategic competencies have traditionally been seen as strategically relevant to a business unit by certain areas of activity in which it is most powerful. The presence of strategic assets and competences provides the enterprise with a sustainable competitive advantage, which in turn is characterized by its importance and long-term viability.

There are quite a number of theoretical approaches to assessing the competitiveness of an enterprise. In this paper, such an assessment is proposed to be conducted on the basis of the competitive potential. The competitive potential of the enterprise includes: financial, labor, management, innovation potential, the potential of basic business processes. Each component of the competitive potential is proposed to be evaluated on the basis of selected indicators, taking into account coefficients set by experts. The competitive potential of the bakeries surveyed for 2014-2018 is shown in table 3.

Table 3

The competitive potential of bakery enterprises, 2014-2018*

\begin{tabular}{|l|c|c|c|c|c|c|}
\hline \multicolumn{1}{|c|}{ Bakeries } & 2014 & 2015 & 2016 & 2017 & 2018 & In average \\
\hline PJSC “Odessa Cow” & 30,15 & 28,52 & 30,71 & 32,31 & 32,53 & 30,84 \\
\hline PJSC «Nikolaevkhlib» & 35,22 & 34,66 & 36,65 & 35,64 & 36,46 & 35,73 \\
\hline Berezovsky Bakery & 38,37 & 39,61 & 41,71 & 44,56 & 44,14 & 41,68 \\
\hline PJSC "Kherson Bakery" & 37,99 & 38,45 & 38,79 & 40,79 & 41,97 & 39,60 \\
\hline
\end{tabular}

* calculated by the author based on enterprise data

As can be seen from Table 3, the range of fluctuations in the competitive potential of bakeries is quite wide. Analysis of the components of the competitive potential allows us to identify such trends. Regarding the financial potential, one can note the high level of instability of financial resources formation. The analysis of the level and dynamics of the potential of major business processes has identified a group of enterprises that have significant problems in the production area, due to the lack of flexible production processes, automated control systems, low coordination of supply and sales systems.
The level of innovation potential in most of the analyzed enterprises tends to increase. Enterprises are currently investing in innovative technological developments in new formulations.

The author proposes to supplement the capacity assessment toolkit with its use indices. There are three types of competitive potential assessment:

- possible competitive potential (MCP), which reflects the creation of maximum sustainable competitive advantages of the enterprise.

- Planned Competitive Potential (CPA), which 
reflects the planned level of competitive potential.

- actual competitive potential (FCP), which reflects the current level of creation and use of sustainable competitive advantages of the enterprise.

The indices proposed for the calculation can be used as a tool for strategic management of the enterprise competitiveness.
In the paper the possible level of the competitive potential was calculated, which reflects the creation of maximum sustainable competitive advantages of the enterprise. This allowed us to determine the current competitive position of the company and to calculate the index of actual use of the competitive potential.

Indices of actual utilization of the competitive potential at bakeries, 2014-2018*

\begin{tabular}{|l|c|c|c|c|c|c|}
\hline \multicolumn{1}{|c|}{ Bakeries } & 2014 & 2015 & 2016 & 2017 & 2018 & In average \\
\hline PJSC “Odessa Cow” & 0,49 & 0,46 & 0,50 & 0,53 & 0,53 & 0,50 \\
\hline PJSC «Nikolaevkhlib» & 0,57 & 0,57 & 0,60 & 0,58 & 0,59 & 0,58 \\
\hline Berezovsky Bakery & 0,63 & 0,65 & 0,68 & 0,73 & 0,72 & 0,68 \\
\hline PJSC "Kherson Bakery" & 0,62 & 0,63 & 0,63 & 0,67 & 0,69 & 0,65 \\
\hline
\end{tabular}

* calculated by the author based on enterprise data

As can be seen from Table 4, the indices of actual use of competitive potential fluctuate on average from 0,50 to 0,72 . Thus, enterprises have different levels of utilization of competitive potential, so they need to develop different strategies that ensure the formation of sustainable competitive advantages.

Conclusions and prospects of the further investigations. The study allowed us to make the following conclusions and suggestions:

1. For enterprises with a high level of utilization of the competitive potential, the most appropriate one will be a cost-saving strategy based on the fullest possible use of the scale effect (a strategy of concentration and specialization in the segment of socially significant bread varieties).

2. For enterprises with an average level of use of the competitive potential, an integration strategy may be recommended: production and sale of semi-finished products for small enterprises (mini-bakeries). In this case, companies have the opportunity to take a relatively free part of the market and create long-term competitive advantages.

3. A differentiation strategy may be recommended for an enterprise with a low competitive potential.

4. A niche strategy should be one of the key strategies for the development of an industry that provides sustainable competitive advantages. Managing the competitive edge of the businesses being researched should be related to the product component. Enterprises should focus on the first segment of socially significant bread varieties, and there are undeniable competitive advantages in this segment. These include:

1) many industrial bakery enterprises are state or municipal property, which facilitates the state's interaction with these enterprises; ty bread;

2) large industrial bakeries provide higher quali-

3) industrial bakeries can provide large orders for bread production.

The segment of socially significant bread varieties should be regulated by the state. Currently, the price level in this segment is regulated by the state. However, according to the author, such measures are not enough. This is due to the fact that raising prices for grain and flour, if the bread prices are constant, can cause losses for businesses. These losses are covered by the production of other types of bread. For businesses, it is necessary to create the conditions under which a sufficient level of profitability will be ensured. Therefore, the state needs to harmonize the pricing system for flour and bread in order to ensure balanced interests of all producer groups in this chain.

5. It is established that one of the most promising segments of the bread and bakery market is the market of large retail chains. However, many networks are currently creating their own bread bakeries, which they sell on their own network. Major bakeries do not stand up to competition in this segment. At the same time, the socalled "American" model of the bread and bread market has become quite widespread. In this model, there are several big players in the market who produce bread and market it as a whole. The use of the positive aspects of the "American" bread market model in relation to Ukrainian conditions allows us to identify two directions of strategic development:

1) integration of bakeries in different forms;

2) participation in the production of bread and bakery products for large retail chains.

In the second direction, it is promising to supply semi-finished products to the bakeries for baking bread in their own bakeries. Bakery businesses can occupy this niche. This will open the prospect of winning another additional segment - the sale of frozen products. The production of frozen semi-finished products requires integration with a number of industries and the creation of a cluster. The supporting industries of such a cluster include warehousing, transport, packaging, sugar, dairy, canning and flour.

The integration of bakeries for the production of frozen semi-finished baked goods and baked goods will allow to obtain a sustainable competitive advantage linked to increased production and the capture of new markets. The integration of bakeries will improve their competitive advantage by increasing all the components of their competitive potential. 


\title{
References
}

1. Derzhavna sluzhba statystyky Ukrainy. (2017). Statystychnyi shchorichnyi Ukrainy za 2017 r. Kyiv.

2. Ohliad rynku khlibobulochnykh i boroshnianykh kondyterskykh vyrobiv v Ukraini. (2019). Retrieved October 2, 2019, from https://pro-consulting.ua .

3. Nikishyna, O. V., \& Bibikova, N. O. (2018). Intehratsiini mekhanizmy rozvytku ukrainskoho rynku khliba ta khlibobulochnykh vyrobiv. Ekonomika Kharchovoi Promyslovosti., 10(1), 16-24. doi: 10.15673/fie.v10i1.862

4. Kovalenko, L. A. (2015). Konkurentsiia u khlibobulochnii promyslovosti Ukrainy. Naukovyi Visnyk Khersonskoho Derzhavnoho Universytetu, 1(12), 112-115.

5. Navolska, N. V. (2018). Doslidzhennia rynku khliba ta khlibobulochnykh vyrobiv v Ukraini. Hlobalni Ta Natsionalni Problemy Ekonomiky, 1(11), 438-431.

6. Ofitsialnyiy sayt APK-Inform. (2019). Retrieved October 14, 2019, from http://www.apk-inform.com .

7. Soloviov, I. O., \& Murzak, O. O. (2017). Marketynhovi aspekty diialnosti sub'iektiv rynku khlibobulochnykh vyrobiv. Ekonomika APK, 2(1), 100-106.

8. Petrukha, S. V., \& Kolotusha, M. M. (2016). Metodolohiia analizu finansovykh rezultativ roboty khlibopekarskoi pidhaluzi kharchovoi promyslovosti Ukrainy. Aktualni Problemy Ekonomiky, 4(10), 118-137.

9. Hlebnyiy biznes: novyie realii - novyie zadachi. (2019). Retrieved October 3, 2019, from http://www.ukrhlibprom.org.ua.

10. Skopenko, N. S. (2018). Suchasni tendentsii intehratsii ta kontsentratsii v khlibopekarskii haluzi Ukrainy. Naukovi Pratsi, 1(38), 420-424.

11. Fedulova, I. V., \& Stretovych, O. A. (2016). Metodychni pidkhody do formuvannia innovatsiinoi stratehii pidpryiemstv khlibopekarnoi haluzi. Ekonomika: Problemy Teorii Ta Praktyky, 4(214), 1186-1193.

12. Ofitsiinyi sait ahrarnoho informatsiinoho ahentstva Agravery. (2019). Retrieved October 19, 2019, from https://agravery.com.

Received 25 October2019

Approved 7 November 2019

Available in Internet 26.12.2019

\author{
Дурбалова Н.И. \\ аспирант \\ кафедра менеджмента и логистики \\ E-mail: durbalova.nataly@ukr.net \\ ORCID: 000-0002-0739-1265 \\ Седикова И.А. \\ доктор экономических наук, профессор \\ кафедра менеджмента и логистики \\ Одесская национальная академия пищевых технологий \\ ул. Канатная, 112, г. Одесса, Украина, 65039 \\ E-mail: irina-sedikova@ukr.net \\ ORCID ID: 0000-0003-4376-1267
}

\section{СТРАТЕГИЧЕСКОЕ УПРАВЛЕНИЕ КОНКУРЕНТНИМ ПОТЕНЦИАЛОМ ПРЕДПРИЯТИЯ}

Современный этап развития пищевой промышленности характеризуется повышением конкуренции на продовольственном рынке, на который выходят новые крупные игроки, что приводит к значительному перераспределению рыночного влияния. Так, предложение на рынке хлеба и хлебобулочных изделий в настоящее время формируется не только крупными промышленными производителями, но и малыми предприятиями и розничными торговыми сетями.

Стратегическое управление позволяет предприятиям увеличить горизонт планирования, обеспечить эффрективное управление конкурентными преимуществами. В то же время проблема стратегического управления конкурентоспособностью предприятий остается пока недостаточно разработанной. Таким образом, практическая значимость и недостаточная научная проработка вопросов управления конкурентоспособностью предприятий в рыночной среде определила актуальность и необходимость данного исследования. 
Целью данной статьи является научное обоснование методов и разработка инструментов управления конкурентным потенциалом предприятий.

В исследовании намечены основные стратегии развития хлебопекарной промышленности, а именно: для предприятий с высоким уровнем использования конкурентного потенциала будет наиболее приемлемой экономически эффеективная стратегия; для предприятий со средним уровнем использования конкурентного потенциала рекомендуется стратегия интеграции; стратегия дифференциации рекомендуется для предприятия с низким конкурентным потенциалом. Было подчеркнуто, что нишевая стратегия должна быть одной из ключевых стратегий развития отрасли, обеспечивающей устойчивые конкурентные преимущества. Управление конкурентным преимуществом исследуемых предприятий должно быть связано с компонентом продукта.

Ключевые слова: стратегия, пекарни, конкуренция, рынок, потенциал.

\author{
Дурбалова Н.I. \\ аспірант \\ кафедра менеджменту та логістики \\ E-mail: durbalova.nataly@ukr.net \\ ORCID: 000-0002-0739-1265 \\ Седікова I.O. \\ доктор економічних наук, професор \\ кафедра менеджменту та логістики \\ Одеська національна академія харчових технологій \\ вул. Канатна, 112, м. Одеса, Україна, 65039 \\ E-mail: irina-sedikova@ukr.net \\ ORCID ID: 0000-0003-4376-1267
}

\title{
СТРАТЕГІЧНЕ УПРАВЛІННЯ КОНКУРЕНТНИМ ПОТЕНЦІАЛОМ ПІДПРИЄМСТВА
}

Сучасний етап розвитку харчової промисловості характеризується підвищенням конкуренції на продовольчому ринку, на який виходять нові великі гравці, що призводить до значного перерозподілу ринкового впливу. Так, пропозиція на ринку хліба та хлібобулочних виробів в даний час фрормується не тільки великими промисловими виробниками, але і малими підприємствами і роздрібними торговими мережами.

Стратегічне управління дозволяє підприємствам збільшити горизонт планування, забезпечити ефективне управління конкурентними перевагами. У той же час проблема стратегічного управління конкурентоспроможністю підприємств залишається поки недостатньо розробленою. Таким чином, практична значимість і недостатня наукова опрацювання питань управління конкурентоспроможністю підприємств в ринковому середовищі визначила актуальність і необхідність даного дослідження.

Метою даної статті $€$ наукове обґрунтування методів і розробка інструментів управління конкурентним потенціалом підприємств.

У дослідженні намічені основні стратегії розвитку хлібопекарської промисловості, а саме: для підприємств з високим рівнем використання конкурентного потенціалу буде найбільш прийнятною економічно ефективна стратегія; для підприємств із середнім рівнем використання конкурентного потенціалу рекомендується стратегія інтеграції; стратегія диференціації рекомендується для підприємства з низьким конкурентним потенціалом. Було підкреслено, що нішева стратегія повинна бути однією з ключових стратегій розвитку галузі, що забезпечує стійкі конкурентні переваги. Управління конкурентною перевагою досліджуваних підприємств має бути пов'язане з компонентом продукту.

Ключові слова: стратегія, пекарня, конкуренція, ринок, потенціал.

\section{Література}

1. Державна служба статистики України. Статистичний щорічний України за 2017 р. Київ, 2017. 533 с.

2. Огляд ринку хлібобулочних і борошняних кондитерських виробів в Україні // Pro-consulting.ua: [Вебсайт]. Одеса, 2019. URL: https://pro-consulting.uа (дата звернення: 02.10.2019).

3. Нікішина О. В., Бібікова Н.О. Інтеграційні механізми розвитку українського ринку хліба та хлібобулочних виробів // Економіка харчової промисловості. 2018. Т. 10, вип. 1. С. 16-24. doi: 10.15673/fie.v10i1.862

4. Коваленко Л. А. Конкуренція у хлібобулочній промисловості України // Науковий вісник Херсонського державного університету / Херсонський державний університет. Херсон, 2015. Т. 1, вип. 12. С. 112-115.

5. Навольська Н. В. Дослідження ринку хліба та хлібобулочних виробів в Україні // Глобальні та національні проблеми економіки. 2018. Т. 1, вип. 11. С. 438-431. 
6. Официальный сайт АПК-Информ: [Веб-сайт]. Одеса, 2019. URL: http://www.apk-inform.com (дата звернення: 14.10.2019).

7. Соловйов І. О., Мурзак О. О. Маркетингові аспекти діяльності суб’єктів ринку хлібобулочних виробів // Економіка АПК. 2017. Т. 2, вип. 1. С. 100-106.

8. Петруха С. В., Колотуша М. М. Методологія аналізу фінансових результатів роботи хлібопекарської підгалузі харчової промисловості України // Актуальні проблеми економіки. 2016. Т. 4, вип. 10. С. $118-137$.

9. Хлебный бизнес: новые реалии - новые задачи // www.ukrhlibprom.org.ua. Одеса, 2019. URL: http://www.ukrhlibprom.org.ua (дата звернення: 03.10.2019).

10. Скопенко Н. С. Сучасні тенденції інтеграції та концентрації в хлібопекарській галузі України // Наукові праці. 2018. Т. 1, вип. 38. С. 420-424.

11. Федулова I. В., Стретович О. А. Методичні підходи до формування інноваційної стратегії підприємств хлібопекарної галузі // Економіка: проблеми теорії та практики. 2016. Т. 4, вип. 214. С. 1186-1193.

12. Офіційний сайт аграрного інформаційного агентства Agravery: [Веб-сайт]. Одесca, 2019. URL: https://agravery.com (дата звернення: 19.10.2019).

Стаття надійшла 25.10.2019

Стаття прийнята до друку 7.11.2019

Доступно в мережі Internet 26.12.2019

Цитування згідно ДСТУ 8302:2015

Durbalova, N. Sedikova, I. (2019). Strategic management competitive potential of the enterprise // Food Industry Economics. 2019. Vol.11, Issue 4. P. 58-64. doi: 10.15673/fie.v11i4.1547

Cite as APA style citation

Durbalova, N., \& Sedikova, I. (2019). Strategic management competitive potential of the enterprise. Food Industry Economics, 11(4), 58-64. doi: 10.15673/fie.v11i4.1547 